\title{
CHARACTERIZATION OF AL-SI ALLOY - BASED NANOCOMPOSITES PRODUCED BY THE ADDITION OF AL-TI5-B1 TO THE MATRIX MELT
}

\author{
Hashem F. El-labban ${ }^{1}$, M. Abdelaziz ${ }^{2}$ and Essam R. I. Mahmoud ${ }^{3}$ \\ ${ }^{1}$ Production Engineering Dept., Alexandria University, Alex. , Egypt. \\ ${ }^{2}$ Composite Materials Lab., Advanced Materials Dept., CMRDI, Cairo, Egypt. \\ ${ }^{3}$ Welding and NDT Lab., Manufacturing Technology Dept., CMRDI, Cairo, Egypt.
}

\begin{abstract}
:
The present study is an attempt to produce aluminum matrix nanocomposites using $\mathrm{Al}-\mathrm{Si}$ alloy as a matrix material and reinforced with hard and stable fine (nano-sized) precipitates. Therefore, Al-Ti5-B1 master alloy and Al-Si alloy of high silicon content were proposed for preparation of such nanocomposites. Three nanocomposites were prepared by adding Al-Ti5-B1 of three different percentages $(1,2$, and $3 \mathrm{wt} . \%)$ to the melt of the Al-Si alloy at $710{ }^{\circ} \mathrm{C}$ for a holding time of 10 minutes and application of mechanical stirring at this temperature. Finally, the treated melt was squeeze cast. The microstructures were investigated using optical and scanning electron microscopes. Phases and different constituents were analyzed with the aid of EDX and XRD analyzers. The addition of Al-Ti5-B1 master alloy with any percentages (even $1 \mathrm{wt}$. \%) to the melt of aluminum alloy, led to remarkable decrease of the matrix grain size. Moreover, many fine precipitates were detected within the $\mathrm{Al}-\mathrm{Si}$ matrix such as $\mathrm{TiAl}_{3}$ phase in the form of flaky and blocky morphology, and $\mathrm{TiB}_{2}$ phase in the nano-sized particles. These precipitates act as heterogeneous sites for nucleation during solidification. The addition of Al-Ti5-B1 master alloy to the Al-Si base metal led to remarkable increase in the average hardness. As the added percentage of Al-Ti5-B1 master alloy is increased, the average hardness value is increased. The average hardness of addition of 3 wt. \% Al-Ti5-B1 master alloy reached $130 \mathrm{HV}$, which was almost twice as high as the hardness of the Al-Si base metal.
\end{abstract}

KEY WORDS:Aluminium grain refinement; Al-Ti5-B1 master alloy; $\mathrm{TiB}_{2}$ particles; $\mathrm{TiAl}_{3}$ intermetallic compounds; Aluminium matrix nanocomposites; Hardness; Wear resistance.

\section{CARACTERISATION DE AL-SI ALLIAGE - NANOCOMPOSITES A BASE PRODUITE PAR L'ADDITION DE AL-TI5-B1 A LA FONTE DE MATRIX}

\section{RÉSUMÉ:}

La présente étude est une tentative pour produire des nanocomposites à matrice d'aluminium en utilisant l'alliage Al-Si en tant que matériau de matrice et renforcé par des fines dur et stable ( de taille nanométrique ) précipite . Par conséquent, Al- Ti5 - B1 alliage maître et Al-Si alliage de haute teneur en silicium ont été proposés pour la préparation de ces nanocomposites . Trois nanocomposites ont été préparés en ajoutant Al- Ti5 -B1 de trois pourcentages différents ( 1 , 2, et 3 en poids . \% ) De la masse fondue de l'alliage $\mathrm{Al}-\mathrm{Si}$ à $710^{\circ} \mathrm{C}$ pendant un temps de maintien de 10 minutes et l'application de la mécanique agitation à cette température. Enfin, la fusion a été traitée compression fonte. Les microstructures ont été étudiées à l'aide de microscopes électroniques optiques et de numérisation. Phases et différents constituants ont été analysés à l'aide d' EDX et DRX analyseurs . L'addition d' Al- Ti5 -B1 alliage maître avec des pourcentages (même une wt . \% ) À l' état fondu de l'alliage d'aluminium , conduit à la diminution remarquable de la taille des grains de la matrice. En outre, de nombreux précipités fins ont été détectées dans la matrice de Al-Si comme phase de TiAl3 sous la forme d' une morphologie feuilletée et sous forme de blocs, et la phase de TiB2 dans les particules de taille nanométrique. Ces précipités agissent comme des sites de nucléation hétérogènes lors de la solidification . L'addition d' Al- Ti5 -B1 alliage maître à la base métallique Al-Si a conduit à une augmentation remarquable de la dureté moyenne. Comme le pourcentage supplémentaire d' Al- Ti5 -B1 alliage maître est augmentée, la valeur moyenne de dureté est augmentée. La dureté moyenne de plus de 3 en poids . \% Al- Ti5 - B1 maitre alliage atteint 130 HV, qui était presque deux fois plus élevée que la dureté de la base métallique Al-Si .

MOTS CLÉS: affinement du grain en aluminium ; Al- Ti5 - B1 maître alliage ; particules TiB2 ; composés intermétalliques TiAl3 ; aluminium matrice nanocomposites ; Dureté Résistance à l'usure ;

\footnotetext{
* $\quad$ Received: 1/12/2013, accepted: 12/3/2014, Ref. No. 171, (original paper)

+ Contact author (essamibrahim2@yahoo.com)
} 


\section{INTRODUCTION}

For a long period, aluminum alloys were some of the most widely used materials as the matrix of metal matrix composites MMCs, both in research and development and in industrial applications. This is mainly due to the low density of aluminum alloys (the first requirement in most application). Moreover, they are inexpensive in comparison with other low density alloys (such as $\mathrm{Mg}$ or $\mathrm{Ti}$ ) [1]. Nowadays, aluminum metal matrix composites (AMMCs) are one of the advanced engineering materials that have been developed for weight critical applications in the aerospace, defense, marine, and more recently in the automotive and transport industries due to their excellent combination of high specific strength and superior wear resistance. In the automobile sector, AMMCs are used for making various components such as pistons, cylinder heads, connecting rods etc., where the tribological properties of the materials are very important [25]. MMCs with uniform dispersion particles in the range of $10 \mathrm{~nm}-1 \mu \mathrm{m}$ are termed "Metal Matrix Nano-composites" (MMNCs). These nano-composites exhibit more outstanding properties over ordinary MMCs and are assumed to overcome the shortcoming of MMCs such as poor ductility, low fracture toughness and machinability [6].

The widely used particle for reinforcing $\mathrm{Al}$ alloys is SiC. Besides its low density and low cost, SiC enhances an increase in the Young's modulus, hardness and tensile strength. However, these composites suffer from a great loss in ductility and toughness due to the undesirable reactions between $\mathrm{SiC}$ particles and aluminum, yielding $\mathrm{Al}_{4} \mathrm{C}_{3}$ interfacial product, which limits their applications to a certain extent [7]. On the other hand, Titanium diboride $\left(\mathrm{TiB}_{2}\right)$ has distinct advantages over $\mathrm{SiC}$ because of its inertness to aluminum matrix [8,9]. In other words, formation of brittle intermetallic products at the interface between the reinforcement and matrix can be avoided using the $\mathrm{TiB}_{2}$ particles
[8,9]. Moreover, $\mathrm{TiB}_{2}$ particles exhibit high elastic modulus and hardness, high melting point, and electrical conductivity as well as good thermal stability [8]. On the other hand, there was a great limitation on the amount of $\mathrm{TiB}_{2}$ particles added to the matrix due to the higher viscosity of the resultant MMCs [9]. Accordingly; several studies have been conducted to syntheses the in situ $\mathrm{TiB}_{2}$ particulate reinforced Al-based composites with enhanced mechanical properties [10-14].

Moreover, the titanium aluminides; $\mathrm{TiAl}_{3}$ and TiAl, have been considered one of most important reinforcement candidates due to their low density, excellent mechanical properties, especially at high temperatures, and high wear resistance [15-16]. These unique properties of Al based MMCs reinforced with titanium aluminides make them a good candidate to substitute traditional high temperature alloys, such as nickel super alloys, in the aerospace industry, especially in turbine elements $[10,16]$.

Regarding the aluminum matrix, grain refinement is a common way to increase both strength and toughness of the material at ambient temperatures [17-19]. Fine grain structure can be produced by various methods: using grain refiners [19], rapid solidification, mechanical milling/alloying of powder metals, and severe plastic deformation (SPD) [18].

It is expected that addition of Al-Ti5-B1 master alloy to the melted aluminum during casting can achieve almost all the previous advantages by one step. Al-Ti5-B1 master alloy is one of the main grain refiners [19]. In situ aluminum aluminides $\left(\mathrm{Al}_{3} \mathrm{Ti}\right)$ and $\mathrm{TiB}_{2}$ particles can be formed during solidification by the reactions between $\mathrm{Al}$ and $\mathrm{Ti}$, and between $\mathrm{Ti}$ and $\mathrm{B}$ elements [19-24]. The present study has been undertaken to present the feasibility of adding Al-Ti5-B1 master alloy to the melted Al-Si base alloy, and to reveal the grain refinement and any resultant in situ reactions formed during solidification. 


\section{EIJEST}

\section{EXPERIMENTAL WORK}

In this study, Al-Si alloy was used as a base material. The chemical composition of this base material is shown in Table 1. Al-Ti5-B1 master alloy was added in different percentages $(1,2$, and 3 wt. \%) to the melted Al-Si alloy at $710{ }^{\circ} \mathrm{C}$, for a holding time of 10 minutes. Mechanical stirring was applied at this temperature and then squeeze casted. The microstructures of the matrix material (Al-Si alloy) and the resultant intermetallics were investigated using optical and scanning electron microscopes equipped with EDX analyzer. The resulted microstructures were analyzed by X-ray diffractometer, (XRD) to identify experimentally the new phases that were in situ formed inside the Al-Si matrix. The microhardness of the product was also measured with Vickers hardness tester at $200 \mathrm{~g}$ load for $15 \mathrm{~s}$.

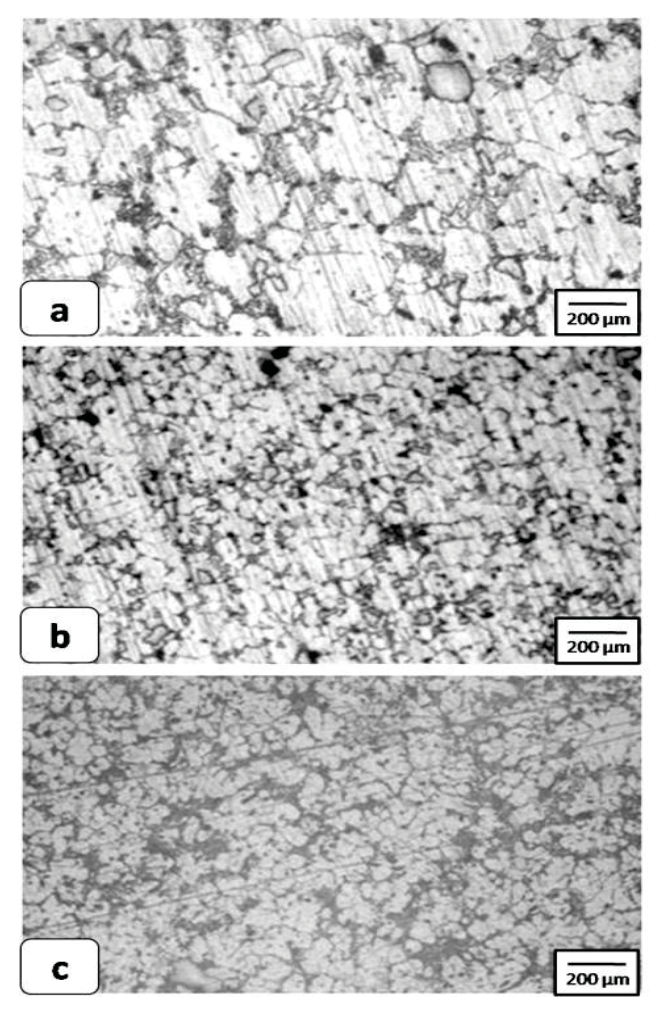

Fig. 1 Optical Microscopic Appearances of: (A) Al-Si Base Metal Without Any Addition, (B) and (C) Base Metal with Addition of 1 and 3\% Al-Ti5B1 Master Alloy, Respectively.

Table 1: Chemical Composition of the Base Aluminum Alloy (Al-Si Alloy); (Wt.\%)

\begin{tabular}{|l|l|l|l|l|l|l|l|l|l|l|}
\hline $\mathrm{Si}$ & $\mathrm{Fe}$ & $\mathrm{Cu}$ & $\mathrm{Mn}$ & $\mathrm{Mg}$ & $\mathrm{Ni}$ & $\mathrm{Ti}$ & $\mathrm{Cr}$ & $\mathrm{Pb}$ & $\mathrm{V}$ & $\mathrm{Al}$ \\
\hline 7.22 & 0.41 & 2.06 & 0.40 & 0.51 & 0.13 & 0.02 & 0.02 & 0.01 & 0.02 & Bal. \\
\hline
\end{tabular}

\section{RESULTS AND DISCUSSIONS:}

\subsection{Microstructure Analysis}

Macroscopic appearance of the Al-Si base metal without any addition together with that produced after addition of Al-Ti5-B1 master alloy with different concentrations, are shown in Fig. 1. Generally, there was a great reduction in $\alpha-\mathrm{Al}$ grain size after the addition of Al-Ti5-B1 master alloy to the Al-Si base metal (compare Fig. 1 (a) with Fig. 1 (b) and (c)). This is may be due to that the grain refinement needs a very small amount of Al-Ti5-B1 master alloy $(\sim 0.2$ wt.\%).
The extra amount will be precipitated as reinforcing particles. Figures 2 and 3 show the scanning electron micrographs for the microstructures of $\mathrm{Al}-\mathrm{Si}$ base metal treated by the addition of Al-Ti5-B1 master alloy with concentration of 1 and $3 \%$, respectively. At lower magnifications (Fig. 2 (a) and Fig 3(a)), both the microstructures show fine dendrite eutectic morphology structure inside $\alpha-\mathrm{Al}$ grains. These dendrite structures are formed from the Si content of the base metal. Note that the dendrite arm spacing of microstructure produced by addition of 3\% Al-Ti5-B1 master alloy is finer than that of addition of $1 \%$ 
(compare Fig. 2 (a) with Fig. 3 (a)). Moreover, many precipitates are detected inside the $\mathrm{Al}$ matrix. At higher magnifications, these precipitates appeared in the form of relatively large flakes and blocks in the Al matrix, especially at the grain boundaries, as clearly shown in Figs. 2(c) and 3(c). By the aid of the EDX analysis, these flaky and blocky morphology precipitates are most probably TiAl3 intermetallics (See Figs. 4 and 5). By comparing SEM micrographs of Figs. 2 and 3, the percentage of precipitated TiAl3 phase is greater in case of addition 3\% Al-Ti5-B1 master alloy (Fig. 3) than that of addition of 1\% (Fig. 2). Moreover, many other fine precipitates appeared inside the grains (almost in the grain center). These precipitates are most probably TiB2 particles. The presence of the TiB2 and TiAl3 were confirmed by XRD analyses; Fig. 7.

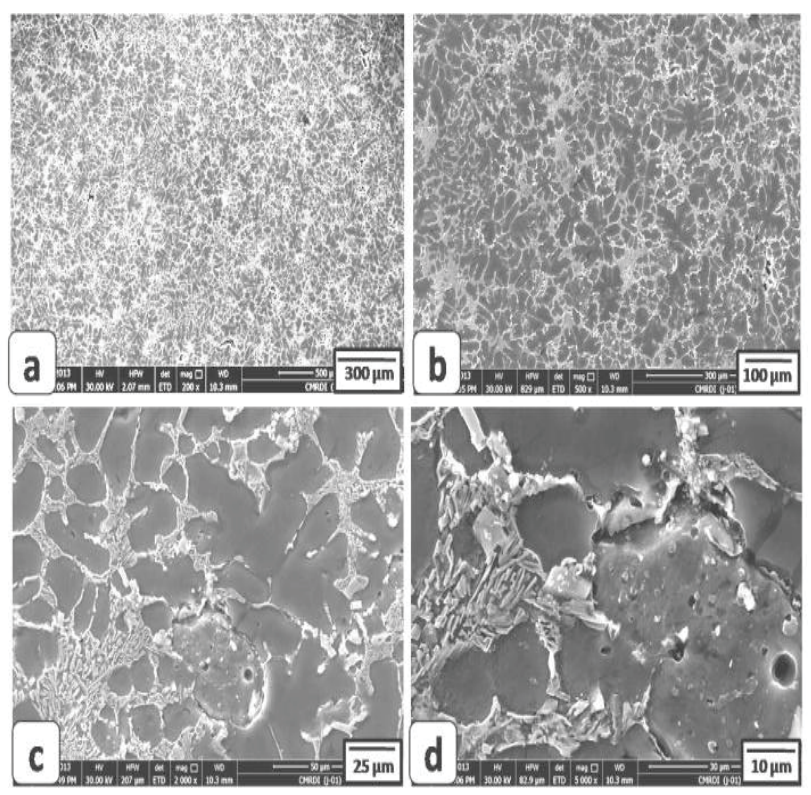

Fig. 2 Different Magnified SEM Micrographs of Al- Si Base Metal with Addition of 1\% AlTi5-B1 Master Alloy.
The fine TiB2 and TiAl3 precipitates are considered as heterogeneous sites for nucleation during solidification, and also as obstacles for grain growth, which lead to grain refinement. At higher magnified micrographs, as shown in Figs. 2 (d) and 3(d), the eutectic dendrites at the grain boundaries are very short. No normal long needle eutectic silicon is appeared. This means that the formation of in-situ $\mathrm{TiB}_{2}$ and $\mathrm{TiAl}_{3}$ particles not only refine the matrix grains but also change the eutectic structure into short forms.

The XRD pattern of the sample that had addition of 3\% Al-Ti5-B1 master alloy is shown in Fig. 7. It was clear that there were $\mathrm{TiB}_{2}$ and $\mathrm{TiAl}_{3}$ phases in addition to that of the base metal; $\mathrm{Al}$ and $\mathrm{Si}$, which confirms the microstructure analysis.

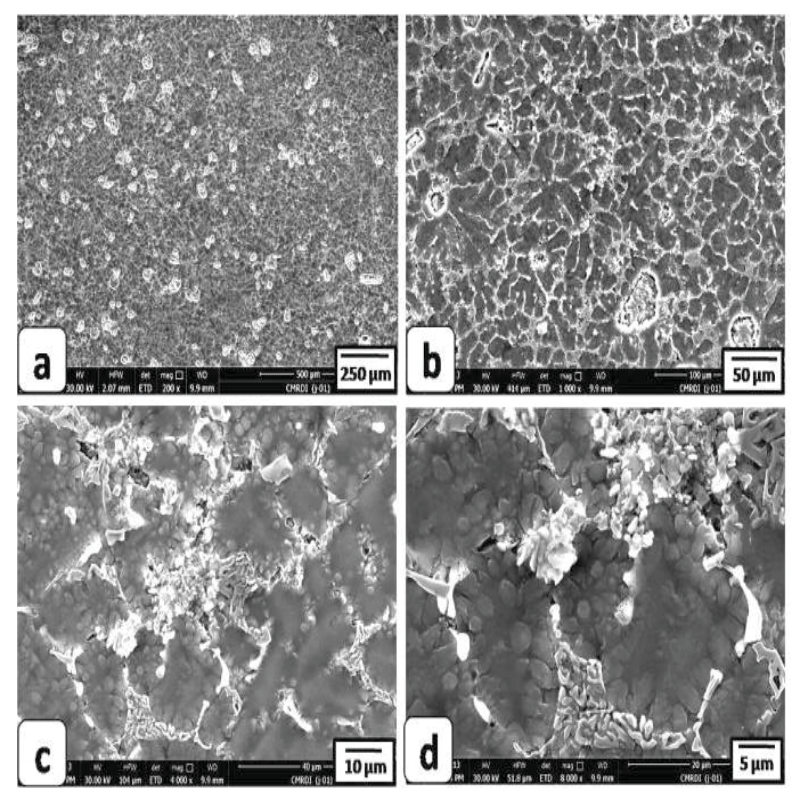

Fig. 3 Different Magnified SEM Micrographs of Al-Si Base Metal with Addition of 3\% AlTi5-B1 Master Alloy. 


\section{EIJES}

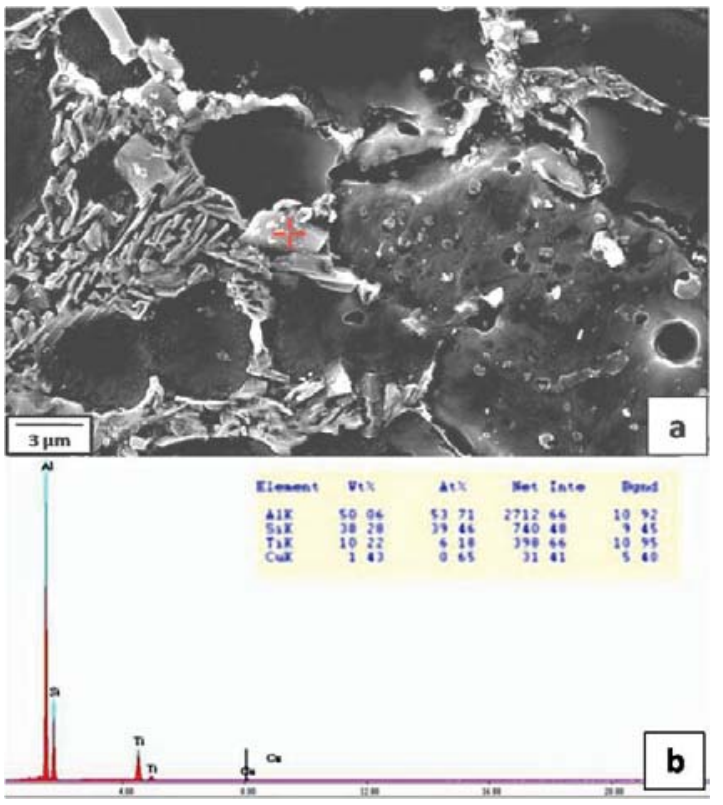

Fig. 4 EDS Spectra of the Cross Mark in SEM Micrographs of Al-Si Base Metal with Addition of 1\% Fig. 6 EDS Spectra of the Cross Mark in A grain Center of Al-Si Base Metal with Addition of 1\% Al-Ti5-B1 Master Alloy

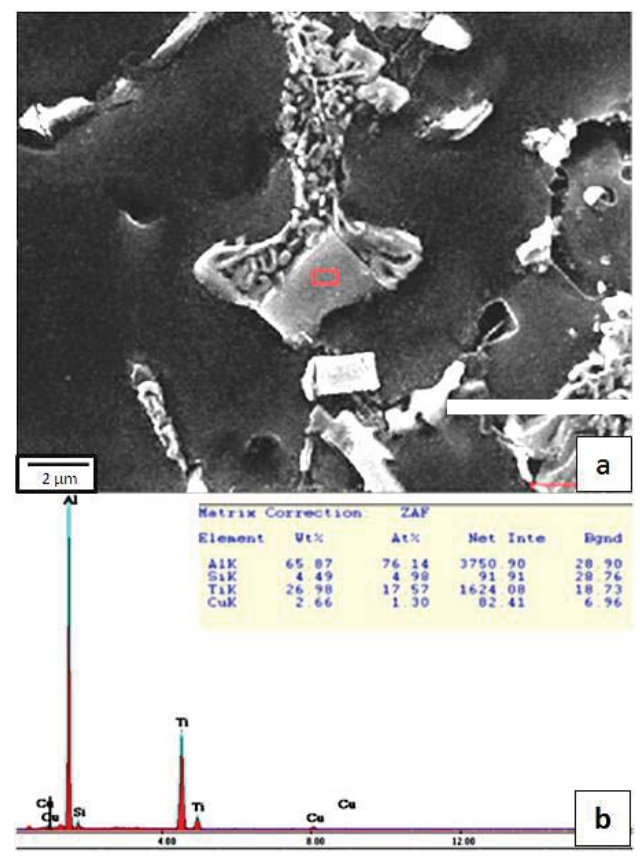

Fig. 5 EDS Spectra of the Red Mark in SEM Micrographs of Al-Si Base Metal with Addition of 3\% Al-Ti5-B1 Master Alloy.

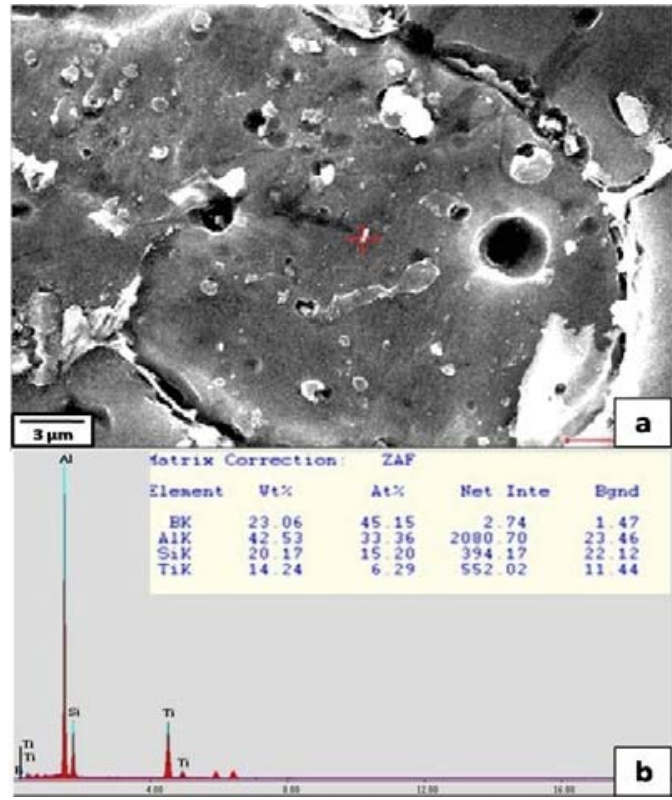

Fig. 6 EDS Spectra of the Cross Mark in A grain Center of Al-Si Base Metal with Addition of 1\% Al-Ti5-B1 Master Alloy.

\subsection{Microhardness Measurements}

Microhardness of the base material and the prepared nanocomposites was measured using microhardness tester, and the measured values are presented in Fig. 8. It is clear that the addition of Al-Ti5-B1 master alloy to the Al-Si base metal led to remarkable increase in the average hardness. As the added percentage of Al-Ti5-B1 master alloy is increased, the average hardness value is increased. The average hardness of addition of 3\% Al-Ti5-B1 master alloy reached $130 \mathrm{HV}$, which was almost twice as high as the hardness of the Al-Si base metal.

This increment in hardness values by addition of Al-Ti5-B1 master alloy to the Al-Si base metal is may be mainly due to two reasons. Firstly, the grain refinement of the base metal can share in this increment. Secondly, the formation of insitu fine $\mathrm{TiB}_{2}$ and $\mathrm{TiAl}_{3}$ precipitates inside the $\mathrm{Al}$ matrix. These fine precipitates are very hard, very stable even at high temperature, and they 
can be considered as reinforcement candidates, as reported by other investigators [8-10].

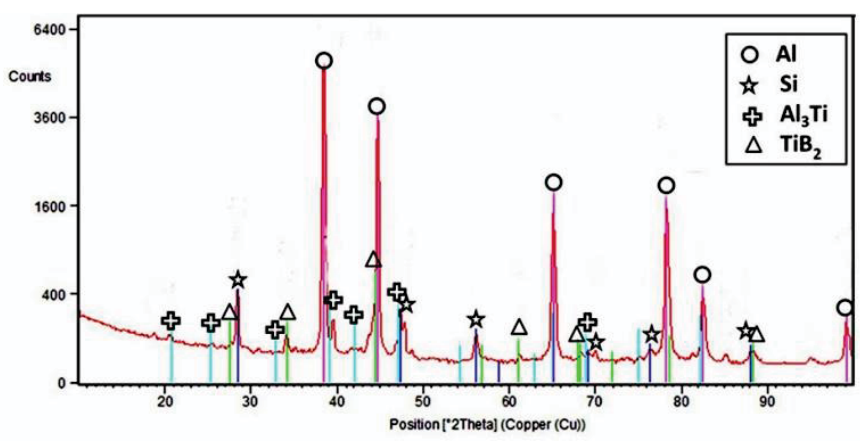

Fig. 7 XRD Pattern of the Sample That Had Addition of 3\% Al-Ti5-B1 Master Alloy.

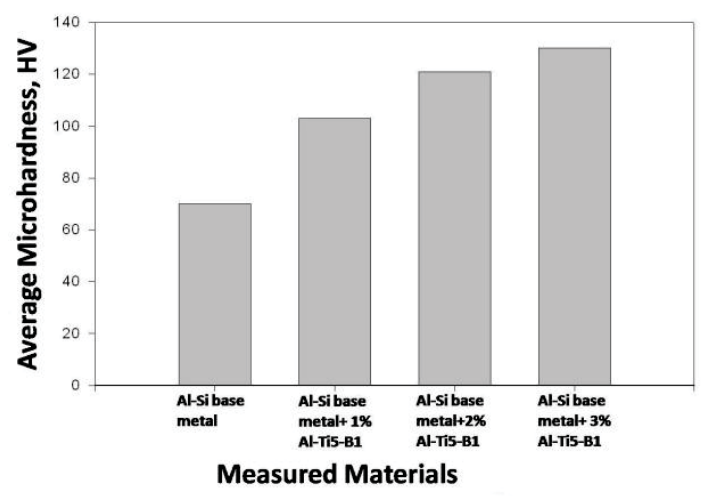

Fig. 8 Average (of Five Values for) Microhardness of Al-Si Base Metal and with Addition of 1\% Al-Ti5-B1 Master Alloy with Different Concentration.

\section{CONCLUSIONS}

This work presented a detailed study on the effect resulted from addition of Al-Ti5-B1 master alloy in different percentages $(1,2$, and 3 wt. \%) to the melt of considered Al-Si base metal at $710{ }^{\circ} \mathrm{C}$ for a holding time of 10 minutes and application of mechanical stirring and squeeze casting. The concluding results obtained can be summarized as follows:

1. The addition of Al-Ti5-B1 master alloy with any percentages (even 1 wt. \%) to the melt of investigated aluminum alloy, led to remarkable decrease of the matrix grain size.

2. The addition of Al-Ti5-B1 master alloy to the Al-Si alloy led to fine eutectic dendrites at the boundaries of $\alpha-\mathrm{Al}$ grains.

3. Many fine precipitates were detected within the $\mathrm{Al}-\mathrm{Si}$ matrix such as $\mathrm{TiAl}_{3}$ phase in the form of flaky and blocky morphology, and $\mathrm{TiB}_{2}$ phase in the nanosized particles.

4. Addition of Al-Ti5-B1 master alloy to the Al-Si alloy had remarkable improvements in hardness. The hardness was increased to about $130 \mathrm{HV}$ for addition of 3\% Al-Ti5-B1 master alloy compared with about $70 \mathrm{HV}$ of the Al-Si base metal.

\section{REFERENCES:}

1. C. F. Feng and L. Froyen: Journal of Materials Science, 35 (2000) 837-850.

2. Yung-Chang Kang and Sammy Lap-Ip Chan: Materials Chemistry and Physics, 85 (2004) 438-443.

3. S.A. Sajjadi, H.R. Ezatpour and M. Torabi Parizi: Materials and Design, 34 (2012) 106-111.

4. Rakesh Kumar Yadav, Nabi Hasan and Ashu Yadav: International Journal of Computer Science and Management Studies, 11, 02, (2011) 2231-5268. 
EIJEST 5. D. Storjohann, O. M. Barabash, S. S. Babu, S. A. David and P. S. Sklad: Metall. Mater. Trans. A, 36A (2005) 3237-3247.

6. Hao Yu: M.Sc. in Material Science \& Engineering, April 2010, WORCESTER POLYTECHNIC INSTITUTE.

7. E. R. I. Mahmoud, K. Ikeuchi and M. Takahashi: Journal of Science and Technology of Welding and Joining, 13 (7) 2007, P. 607-618.

8. J.F. Shackelford and W. Alexander, CRC Materials Science and Engineering Handbook. 3rd ed., CRC Press, Boca Raton, FL, 2001.

9. N.L.Yue, L. $\mathrm{Lu}$ and M.O. Lai: Composite Structures, 47 (1999) 691694.

10. M.D. Salvador, V. Amigo, N. Martinez and D.J. Busquets: Journal of Materials Processing Technology, 143-144 (2003) 605.

11. S.C. Tjong and H.W. Huo: Journal of Materials Engineering and Performance, 18, 1 (2009) 88-94.

12. T. Nukami and M.C. Flemings: Metall. Mater. Trans. A, 26 (1995) 1877-1884.

13. P. Li, E.G. Kandalova, and V.I. Nikitin: Mater. Lett.,59 (2005) 2545-2548

14. K. Sivaprasada, S. P. Kumaresh Babua, S. Natarajana: Materials Science and Engineering, A, 498 (2008) 495-500.

15. M. Adamiak: Journal of Achievements in Materials and Manufacturing Engineering, 14, 1-2 (2006) 157.
16. M. Adamiak, J.B. Fogagnolo, E.M. Ruiz Navas, L.A. Dobrzaski and J.M. Torralba: Journal of Materials Processing Technology, 155-156 (2004) 2002.

17. X.Wang, A.Jha and R.Brydson: Materials Science and Engineering A, 364 (2004) 339-345.

18. MOHANTY P S and GRUZLESKI J E.: Acta Metallurgica et Materialia, 43 (1995) 2001-2012.

19. MCCARTNEY D. G.: International Materials Reviews, 34 (1989) p. 247.

20. YI H Z, MA N H, ZHANG Y J, LI X F and WANG H W: Scripta Materialia,54 (2006) 1093-1097.

21. KRISHNANA T S, RAJAGOPALANA P K, CUNDB B R and BOSEC D K.: Journal of Alloys and Compounds, 269 (1998) 138-140.

22. EASTON M A and STJOHN D H.: Acta Materialia, 49 (2001) 1867-1878.

23. NAGLI, A. SMOLEJ and $M$. DOBEREK: METALURGIJA 47, 2 (2008) 115-118.

24. WILLIAM C.: Materials Science and Engineering A, 24 (1998) 75-79. 